\title{
A CORRELATION BETWEEN STUDENTS' LISTENING AND WRITING SKILLS: A STUDY AT AN ISLAMIC BOARDING SCHOOL
}

\author{
Royhan Kamal', Hikmah Pravitasari², Amila Yashila Rahmah³, Siti Febriyanti", Isma Ristiyana5, \\ Nurul Adhanib, Iqbal Rosyid ${ }^{7}$ \\ 1,23,4,5,6,7 English Education Department, Faculty of Teacher Training Education STKIP La Tansa \\ Mashiro, Banten, Indonesia \\ E-Mail: royhan.jabb@gmail.com; hikmah@latansamshiro.ac.id; \\ amilayashilarahmah228@gmail.com; febriyantisiti503@gmail.com; ryanaisma125@gmail.com; \\ haninurul872@gmail.com; rasyidbanihasan@gmail.com
}

\begin{abstract}
The study explored the relationship between listening and writing skills of second-grade junior high school students of an Islamic boarding school in Indonesia. This research aimed at: (1) how is the performance of males and females' listening and writing skills? (2) how is the portrayal of students' listening skills compared to students' writing skills in Islamic boarding schools? and (3) whether there is a correlation between students' listening skills and students' writing skills in Islamic boarding schools? The data was obtained from listening and writing scores. Results showed that $r$-count $>r$-table $(r$-count $=0.8699 ; r$-table $=0.3291)$. It can be concluded that the student's performance in the listening and writing scores was statistically significantly correlated. However, the significant correlation of listening and writing skills in this study is feasibly valid for the context.
\end{abstract}

Keywords: Islamic boarding school, listening skills, writing skills.

\begin{abstract}
Abstrak
Penelitian ini mengeksplorasi hubungan antara keterampilan mendengarkan dan menulis siswa kelas dua sekolah menengah pertama pada salah satu pondok pesantren di Indonesia. Penelitian ini bertujuan untuk: (1) bagaimana kinerja keterampilan mendengar dan menulis siswa laki-laki dan siswa perempuan? (2) bagaimana penggambaran keterampilan menyimak siswa dibandingkan dengan keterampilan menulis siswa di pondok pesantren? dan (3) apakah ada hubungan antara keterampilan menyimak siswa dengan keterampilan menulis siswa di pondok pesantren? Data diperoleh dari skor menyimak dan menulis. Hasil penelitian menunjukkan bahwa r-hitung $>r$-tabel (r-hitung=0,8699; $r$-tabel= 0,3291). Dapat disimpulkan bahwa kinerja siswa dalam skor mendengarkan dan menulis secara statistik berkorelasi signifikan. Namun, korelasi yang signifikan dari keterampilan mendengarkan dan menulis dalam penelitian ini hanya layak untuk konteks penelitian ini saja.
\end{abstract}

Kata kunci: korelasi, Pondok Pesantren, keahlian menyimak, keahlian menulis.

\section{Introduction}

Languages have complex structures and are difficult to define. English includes 4 skills, namely speaking, reading, listening, and writing. Listening is one of the communication skills to receive and interpret message accurately in the communication process. Listening is the key 
to all effective communication. According to Anderson and Lynch (1988, p.6), arguing what is successful listening, understanding is not something that happens because of what a speaker says: the listener has a crucial part to play in the process, by activating various types of knowledge, and by applying what he knows to what he hears and trying to understand what the speaker means. Without the ability to listen effectively, as a result message is easily misunderstood, communication is lost and the sender of the message can easily become frustrated and irritated. Meanwhile, writing skills include all knowledge and abilities related to expressing ideas through written words. Learning to write will take a longer time than learning to speak, because writing requires greater accuracy and variation. Many students feel hard to learn writing, because writing not only need good vocabulary building and grammatical function, but also need a good words and sentences arrangement to make a good written composition (Kim, Crossley, \& Kim, 2020). Some students feel hard to write, because they have low vocabulary mastery and low motivation in writing itself (Bian, Cai, \& Cai, 2019; Staehr, 2008). In addition, they are lazy to write because they think that it is very difficult to keep the objectivity, because they cannot write well and have negative attitudes toward writing instruction.

This research aims at investigating quantitatively: (1) how is the performance of males and females' listening and writing skills? (2) how is the portrayal of students' listening skills compared to students' writing skills in Islamic boarding schools? and (3) whether there is a correlation between students' listening skills and students' writing skills in Islamic boarding schools?

\section{Literature Review}

A number of studies have investigated students' performance in listening and writing skills. Some suggested that listening scores have increased the students' writing scores (Bian, Cai, \& Cai, 2019; Staehr, 2008; Zhu, Li, Yu, Cheong, \& Liao, 2016). Taheri, Sadighi, Bagheri, \& Bavali (2020) argued that learning strategy improve student's language skills achievement. The study also sought to identify possible differences between high and low achieving language learners regarding the frequency and type of their language learning strategies. On the other hand, Zhu, Li, Yu, Cheong, \& Liao (2016) examined that the students' performance in the independent listening task and the listening-reading-writing task was statistically significantly correlated. Meanwhile, three studies reviewed the contribution of vocabulary toward the listening and writing skills accomplishment (Bian, Cai, \& Cai, 2019; Kim, Crossley, \& Kim, 2020; Staehr, 2008). The study revealed that vocabulary size is important for language proficiency. Furthermore, the findings proposed that the 2000 vocabulary level is a crucial learning goal for low-level EFL learners to expand their listening and writing skills (Staehr, 2008). Likewise, Bian, Cai, \& Cai (2019) located stronger correlation between the various kinds of vocabulary knowledge to listening comprehension. Moreover, the study indicated that students' vocabulary knowledge was the most important predictor of both students' reading and writing skills (Kim, Crossley, \& Kim, 2020).

However, in the latest discussion on students' listening and writing skills in the context of learning in Islamic boarding schools have not been widely reported. Thus, the researchers chose to investigate whether there is a correlation between students' listening skills and students' writing skills in Islamic boarding schools. 


\section{Method}

\subsection{Participants}

There were thirty-five participants who were second grade junior high school students of an Islamic boarding school in Indonesia. They were recruited voluntarily in this study. The participants consisted of 16 male students and 19 female students, with age ranging from 13 to 14 years old. For the ethical purpose, pseudonyms were employed in this article. Before the study commenced, the researchers convened a meeting with the participants, distributed informed consent form sheets, and explained the details of an informed consent form. The researchers asked them to read through and sign off the form to ensure that all of the data would be kept confidential and be used for publication purposes. They agreed to sign the consent form as a legal document of their participation in this study. They also deserved the right to withdraw from the study without any penalty. In detail, the demographics of the participants are shown in table 1 and table 2.

\subsection{Data Collection and Analysis}

The data were collected through listening and writing tests. The method used by the researchers in this study is a correlation research method to determine whether the listening ability of second grade junior high school students of Islamic boarding school has an influence on their writing skills. The data were analyzed with Pearson product-moment correlation and Microsoft Excel 2019 to find the relation between students' listening and writing skills.

\section{Finding and Discussion}

\subsection{Males and Females' Listening and Writing Performance}

The diagram below (Figure 1) presents a summary of the student's gender listening score. We can see male and female students have a minimum score of 5.5. The maximum score for male students was 8.5 and female students by 9 .

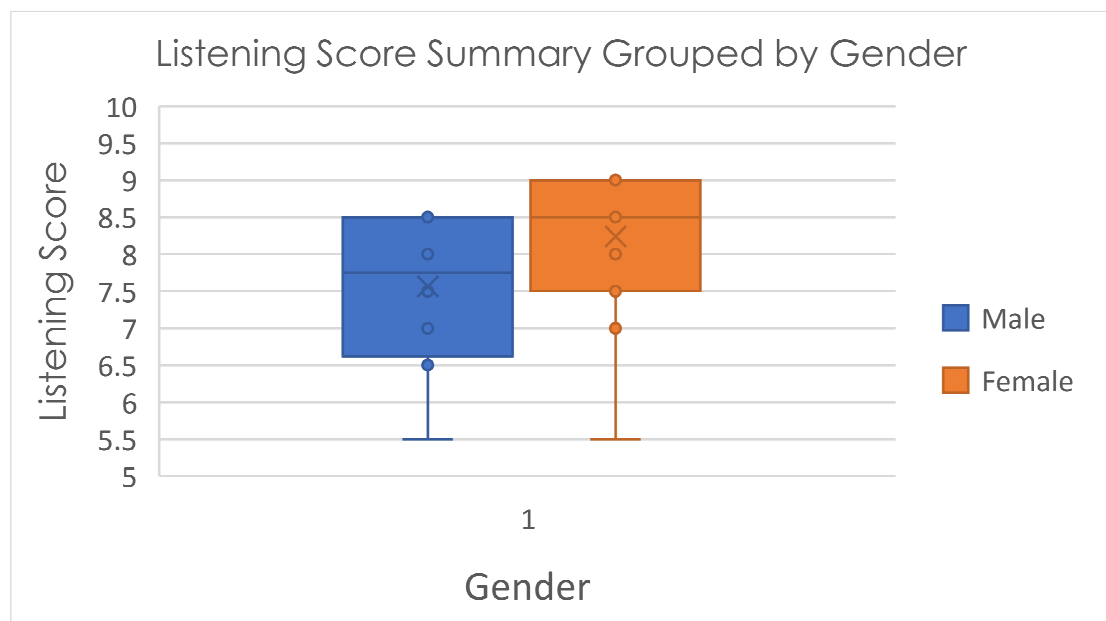

Figure 1. Listening Score Summary Grouped by Gender 


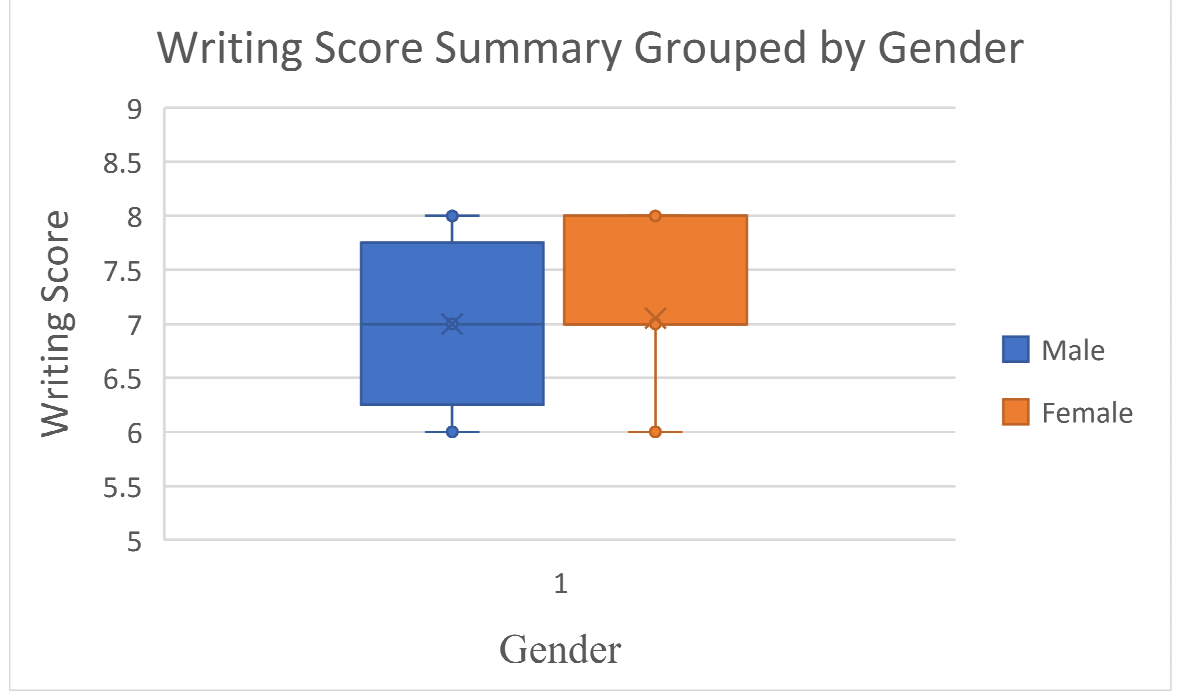

Figure 2. Writing Score Summary Grouped by Gender

The diagram above (Figure 2) presents a summary of writing scores divided based on the student gender. The minimum scores of male and female students were 6. Similarly, male and female students both achieve a maximum of 8 .

4.2 The Portrait of Students' Listening Skills Compared to Students' Writing Skills

Table 1. Listening Score of The Participants

\begin{tabular}{l|cccccccc|c|c}
\multirow{8}{*}{ Gender } & \multicolumn{7}{|c}{ Listening Score } & Total \\
\cline { 2 - 8 } & 5,5 & 6 & 6,5 & 7 & 7,5 & 8 & 8,5 & 9 & \\
\hline Male & 1 & 0 & 3 & 2 & 2 & 2 & 6 & 0 & 35 \\
Female & 1 & 0 & 0 & 2 & 2 & 2 & 4 & 8 & 35
\end{tabular}

Table 1 is a summary of listening score gained from thirty-five of second grade junior high school students as the respondents of this study.

Table 2. Writing Score of The Participants

\begin{tabular}{|c|c|c|c|c|}
\hline \multirow{2}{*}{ Gender } & \multicolumn{3}{|c|}{ Writing Score } & \multirow{2}{*}{ Total } \\
\hline & 6 & 7 & 8 & \\
\hline Male & 4 & 8 & 4 & 35 \\
\hline Female & 4 & 10 & 5 & ט \\
\hline
\end{tabular}


Table 2 is a summary of writing score gained from thirty-five of second grade junior high school students as the respondents of this study.

\subsection{The Correlation Between Students' Listening Skills and Students' Writing Skills}

To know the correlation between listening skills and students' writing skills, the researchers calculated the data by using Microsoft Excel software and gained the correlation score of $r$ count was 0.8699 .

The value of the r-count is then compared with the value of the r-table with error level = 0.05 and degrees of freedom $=35-1=34$. The result of $r$-table $=0.3291$ counted using Pearson product-moment correlation. The ratio of $r$-count with $r$-table suggested that the value of $r$ count is dropped between 0.80 and 1 . Hence, the correlation is significant. However, as viewed from the scatterplot (Figure 3), $x$ variable is not parallel with the $y$ variable. Since each occurrence of value increases the value in variable $x$, the increase in variable $y$ also rises in value as variable $x$. Therefore, while there is a misalignment of values attained by the two variables in the diagram below, both have a value-enhancing phase at the same time.

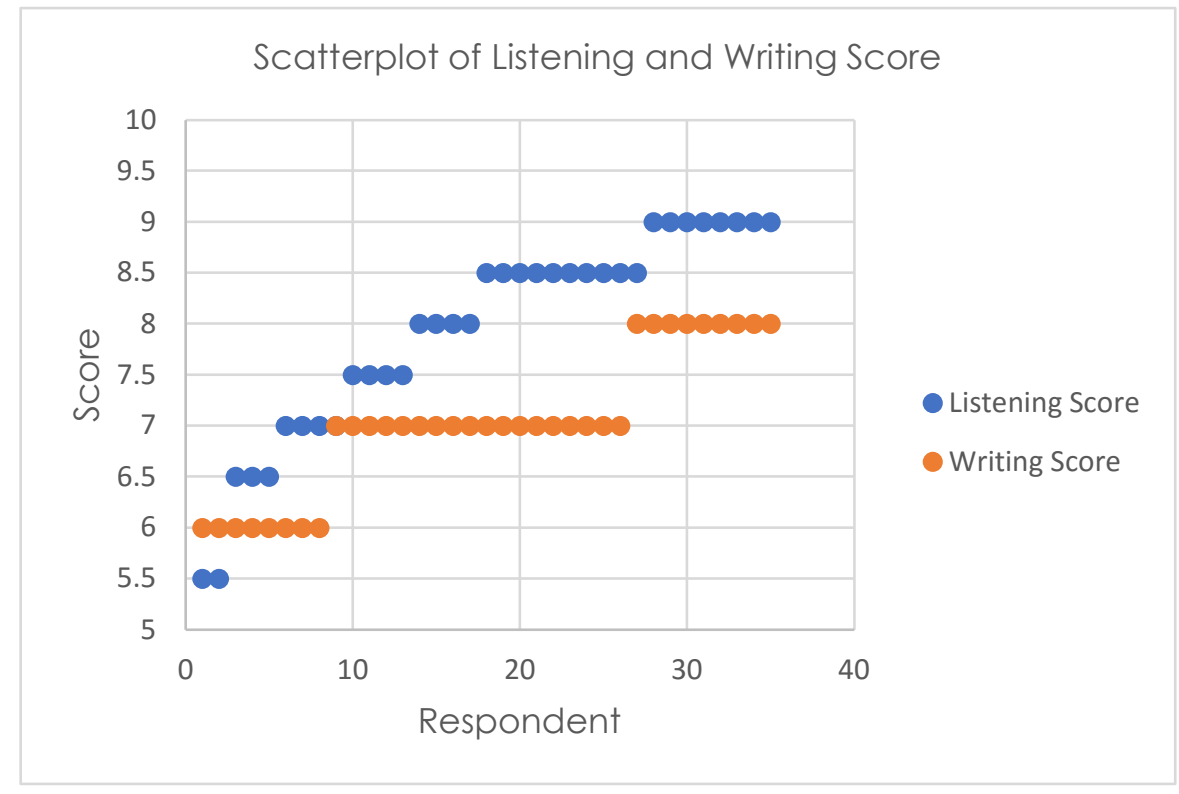

Figure 3. Scatterplot of Listening and Writing Score

The conclusion from the comparison of listening score and writing score on the explanation above demonstrates that the value of gained correlation can be used to measure the correlation or relation between listening score and writing score, which emerged in the limited previous research (Bian, Cai, \& Cai, 2019; Matthews \& Cheng, 2015; Zhu, 2015). For any 
respondents who get an increase in listening score, writing score will be enhanced as well from earlier. Therefore, the phase of increase generated by writing score, which is caused by an increase in listening score describes a correlation between the students' listening ability to writing ability in boarding school.

\section{Conclusion}

This research discovered the significant correlation between listening and writing skills on the second-grade junior high school students of Islamic boarding school in Indonesia. As the data were collected from the limited participants, the generalization of the finding perhaps

valid only for this context. Therefore, further research needs to conduct with larger size of participants.

\section{References}

Anderson, A., \& Lynch, T. (1988). Listening. Oxford: Oxford University Press.

Bian, X., Cai, X., \& Cai, D. (2019). The Contributions of Listening and Reading Vocabularies to Listening Comprehension of Chinese EFL Students. International Journal of Listening, 1 (1), 1-13, DOI: 10.1080/10904018.2019.1623678.

Kim, M., Crossley, S.A., \& Kim, B.K. (2020). Second Language Reading and Writing in Relation to First Language, Vocabulary Knowledge, and Learning Backgrounds. International Journal of Bilingual Education and Bilingualism, DOI: 10.1080/13670050.2020.1838434.

Matthews, J., \& Cheng, J. (2015). Recognition of High frequency words from speech as a predictor of L2 listening comprehension. System, 52, 1-13. doi:10.1016/j.system.2015.04.015.

Staehr, Lars Stenius. (2008). Vocabulary Size and The Skills of Listening, Reading and Writing. The Language Learning Journal, 36(2), 139-152, DOI: 10.1080/09571730802389975.

Taheri, H., Sadighi, F., Bagheri, M.S., \& Bavali, M. (2020). Investigating the Relationship Between Iranian EFL Learners' Use of Language Learning Strategies and Foreign Language Skills Achievement. Cogent Arts \& Humanities, 7(1), 1710944, doi.org/10.1080/23311983.2019.1710944.

Zhu, Xinhua. (2015). Implementing Integrated Testing of Chinese Language in Hong Kong Secondary Schools: The Current Situation and Improvement Strategies. Educational Research, 36(5), 114-121.

Zhu, X., Li, X., Yu, G., Cheong, C.M., \& Liao, X. (2016). Exploring the Relationships Between Independent Listening and Listening-Reading-Writing Tasks in Chinese Language Testing: Toward a Better Understanding of the Construct Underlying Integrated Writing Tasks. Language Assessment Quarterly, 13(3), 167-185, DOI: 10.1080/15434303.2016.1210609. 